\title{
Julian Barnes's The Lemon Table as a Collection of Stories of Absence
}

Julian Barnes'ın Öykü Derlemesi Limon Masası'nda Yokluk

\author{
Buket Doğan \\ Middle East Technical University, Turkey
}

\begin{abstract}
In his collection of short stories, Julian Barnes mainly focuses on the themes of loss and death. Through their stories, Barnes's characters are depicted in glimpses in their long journey which is from their early life to their very old age. Starting from the very first story titled "A Short History of Hairdressing," the main character's kind of metamorphosis into an old man is narrated with ruptures and gaps which seem to be loopholes to be completed for the reader. That the narrator leaves these means of evasion can be evaluated in light of Derrida's reversal of the traditional ordered pairs like presence/absence. While the first term is viewed as primary and original, the second one is derivative in the Western epistemology. Yet, for Derrida this priority is not intact and can easily be reversed as both the primary and the secondary terms are dependent on each other while bearing the traces of one another. In this axis of binary oppositions, man is associated with either presence or primary; on the contrary, woman is absent or subordinate. In the stories under scrutiny here, male protagonists are fully depicted and most of their actions are mostly legitimized. However, female characters are not allowed to contribute to the flow of the fiction; that is, they are accessories and almost show no presence. In this hierarchical space, women are naturally degraded, which in turn prevents men from achieving any kind of intersubjectivity with anyone. Thus, the course of events including even some of the most intimate details about the characters acts as a screen for absence; that is, they fail to give any worthy information about them. The so-called presence of incidents is indeed absence. In this light, it can be concluded that what goes on or what does not go on in Barnes's stories can be discovered amidst the slippery ground where the primary and the secondary terms are reversed and intermingled.

Keywords: Julian Barnes, short stories, deconstructive reading, presence/absence, patriarchal discourse, objectification of women

Öz

Julian Barnes Limon Masası isimli öykü derlemesinde ağırlıklı olarak kayıp ve ölüm temasına odaklanmış ve karakterlerini genelde çok genç yaşlarından yaşlılıklarına uzanan yolculuklarında ele almaya çalışmıştır. Derlemedeki "Kuaförlüğün Kısa Hikayesi" isimli ilk öyküden başlayarak, ana karakterin yaşlı bir adama dönüşümü okuyucu tarafından doldurulmayı bekleyen boşluklarla anlatılmıştır. Anlatıcının bu tip kaçış noktaları bırakması Derrida'nın geleneksel olarak eşleştirilmiş varlık/yokluk gibi ikililerin tersine çevrilmesi ışığında değerlendirilebilir. Batı epistemolojisinde, bu ikilinin ilk ayağı birincil ve orijinal olarak görülürken, ikincisi genellikle ikincil veya türev olarak görülür. Fakat, Derrida için birincilin önceliğinin dokunulmazlığı yoktur
\end{abstract}


ve bu ikili zıtlık tersine çevrilebilir. Böyle ikili zıtlıklar ekseninde, öykülerde incelenen erkek karakterler varlık ya da birincillikle, kadın karakterler ise tabi veya yoklukla ilişkilendirilmiştir. Erkek karakterlerin hareketleri ve motivasyonları açıklanıp mazur gösterilirken, kadın karakterlerin olay akışına etki etmesine izin verilmemiş aksine kadınlar basit bir aksesuar olarak konumlandırılıp hemen hemen hiç varlık göstermemişlerdir. Kadının hor görüldüğü bu hiyerarşik uzamda, erkek de hiçbir bağlamda öznelerarasılı bir ilişkiyi başaramaz. $\mathrm{Bu}$ teorik açılamalar ışığında, Barnes'in öykülerinde gerçekleşen ya da gerçekleşmeyenler birincil ve ikincil terimlerin tersine çevrildiği ya da iç içe geçirildiği kaygan bir zeminde incelenecektir.

Anahtar Kelimeler: Julian Barnes, kısa hikayeler, yapıbozumcu okuma, varlık/yokluk, ataerkil söylem, kadının nesneleştirilmesi

Julian Barnes's The Lemon Table is a collection of eleven short stories all dealing with old age, demise and painful feelings accompanied to death. As the stories lay it bare, protagonists, mostly old men, suffer from not being able to fulfil their potentials in their job, social life or sexual performances with their partners anymore. During their journeys of aging, they feel regretful for their past follies and at times criticize themselves. The characters here all turn old with some sneaking feelings; some with profound regret, some with a mass of stoicism and yet some still with raving defiance. All these bitter feelings are complemented by the recognition of a growing inability to pursue the passions of a younger self. For Stephanie Merritt, in her review of the collection in The Guardian, the most "forceful among these is regret" but what is more tragic is that "Barnes's characters bring an awareness of their own folly for refusing to relinquish the pleasures and passions of the younger self, and a concurrent awareness of a growing inability to pursue those passions with consistent vigour" (Merritt). Rather than the presence of several emotions, it can be noted that these stories are expected to be built on the absence of some prospects or abilities parallel with the theme of the collection. Dealing with the dichotomy of presence and absence, this paper aims to put double entendre on the concept of absence. One leg of the word play refers to the taken-for-granted emotions co-existing with death like the absence of a possibility of active involvement in any sphere of life, be it in social or domestic roles. Especially, the male protagonists are portrayed as angry old men who cannot now appreciate their former mobile and potent ways of taking part in public and private spaces as once they did in their youth. The second leg in the double entendre refers to the absence of a free thirdspace which would have made it possible for the women characters to be depicted in depth and from a multidimensional perspective and it would have welcomed an interplay between binary oppositions. Yet, in this case, with the lack of thirdspace, women characters in the stories are all enslaved into the roles that are assigned by the patriarchal perspective. Those women are, in other words, depicted in the absence of an indulgent thirdspace where they can be stripped of their traditionally attributed roles. This absence can yet be recognized as the presence of a troubled masculine way of looking at women. This reflection of 
troubled masculine and patriarchal identification with the status quo in looking at women will be analysed in this paper by making use of the idea of how the traditionally ordered pair of presence/absence are mutually interrelated and how they exist with the presence and absence of each other.

Absence and presence, these seemingly opposing terms, are indeed taken to be perceived together. Before focusing on how absence is situated as the binary opposition of presence, one may cast an eye on how present entity or presence of meaning is configured in dualistic logic. Logocentric tradition, according to Vincent Leitch, the General Editor of Norton Anthology of Theory and Criticism, "always assigned the origin of truth to the logos - to the spoken word, to the voice of reason, to the word of God" and that voice or that word delegates items which were already "determined as presence: the 'object' of science and metaphysics was characteristically the 'present entity,'” as he gauges Derrida (25). Criticising logocentric thought, deconstructive way of thinking presents an alternative which would be to deny the metaphysics of self-presence and acknowledge that signifieds function as signifers, which argues that meaning is never self-present but it should be traced. So, to Derrida this "present entity" and "determinate and decidable meaning" are an illusion and thus he paves the way for a new way of thinking about language and reality. In Derrida's view, Christopher Norris reports in a nutshell as follows: "meaning is nowhere punctually present in language" (15). In order to track meaning then, the readers should "operate a kind of strategic reversal, seizing on precisely those unregarded details (causal metaphors, footnotes, incidental turns of argument)" which might have been bypassed by a more orthodox look (19). For this kind of a reading, Norris suggests that Derrida's deconstructive move will offer "the dismantling of conceptual oppositions, the taking apart of hierarchical systems of thought which can then be reinscribed within a different order of textual signification" (19). In this kind of an action, Derrida detects the conventionally structured pairs; such as presence/absence, nature/culture, man/woman, speech/writing or philosophy/literature. In this doubling, as Michael P. Spikes infers, while "the first term is viewed as primary and original" the second term is "secondary and derivative" (337). Derrida's reading reverses the priority, "making the second term primary and original and the first term secondary and derivative" (337). Such a reading will then reveal how these two terms are "mutually implicated" and that "each bears the traces of the other within itself" (337). It can be concluded that both the first and the secondary terms are dependent on one another and thus each is a prerequisite for the other to make sense.

From all these theoretical propositions one thing is much clearer than anything else; that is, meaning is never self-present. All signifieds dissolve into strings of ever deferring and differing signifiers. Todd May reads what Derrida concludes about deconstructive analysis as follows: "the operation of language is such that there is always a play between presence and absence" (79). Any intention of signifying then is to be exposed to deferral for good. Thus, it can be suggested that Derrida identifies a level of meaning grounded in non-present 
absence and that the referent is the absence of just bare particularness and properties. Going back to the stories, the characters' metamorphosis into old people are narrated with ruptures and gaps as loopholes that require the reader's involvement in the text to be in pursuit of a deferred meaning.

In each story line, the women characters are somehow not depicted as fully developed characters but rather portrayed as stereotypes complying with the dictations of the patriarchal discourse. To be more specific, these women are there only to serve men for any kind of purpose. In the case of love affairs, they seem to be partners of men; however, they are either devoid of any meaningful contribution to these relationships or they are totally cast out from any performative act that would grant them recognition as spiritual beings as well as with their corporeal appetites. Thus, in Derridean terms, one can assert that they are settled onto an absent-present kind of state. In the first story of the collection titled "A Short History of Hairdressing," Allie is depicted as a kind of commodity or an object who is there only to serve or satisfy Gregory's needs. Allie, Gregory's girlfriend in the second part of the story, then his wife in the third part, is tailored from the vantage of the patriarchal discourse. In this three-part story, we learn that Gregory was happy on those days when Allie used to cut his hair and satisfied his sexual needs at the same time. That is because he did not want to visit the barbershop. Starting with the first part of the story, it is revealed that even as a child, when he visited the barbershop with his mother, he was not at peace with the atmosphere there. In this suburban Barnet shop, Gregory likened the experience to a torture and the barber to "torturer in chief" justifying himself with more details as follows: "Everything else seemed the same; the torture chair, the surgical smells, the strap and the folded razor - folded not in safety but in threat" (3). Feeling insulted and subordinated under the dictations of his mother and the acknowledged rules in the barbershop, Gregory has never been observed to be at ease. When he is twenty-something, Allie is the one to save him from going to this uncanny place by cutting his hair. In the second part of the story, again in the barbershop, Gregory is now found out to be a college student, longhaired and resistant towards societal codes and the status quo. At the same time, it is revealed that he broke up with his girlfriend Allie and is angry with the institution of marriage as he openly supports himself by quoting from Voltaire: "Marriage is the only adventure open to cowardly" (12). The narrator explains the reason why Gregory is there at the barbershop, which is because Gregory and Allie split up, and therefore she is not cutting his hair anymore. That is why he is angry with Allie and marriage as now he is not satisfied in any way. At this point, he identifies a kind of association between sex and haircutting, remembering his previous experiences with his girlfriend, cutting his hair and satisfying his sexual needs in the bathtub, Allie portrayed in a passive light.

The level of meaning in this story is grounded in present absence. The absence of any reasonable and/or emotional explanation for Gregory's yearning for Allie or lack of signs of any intersubjectivity but his depiction of her in a sexual 
scene passively trying to fulfil his partner's needs lays the perception of seeing or presenting woman as a pornographic object bare. In this story, Gregory is simply depicted as a man who "measures out his life in haircuts" as there is almost no other setting where Gregory can be observed ("Book Cover," The Lemon Table). Gregory's story is far from indicating or implying a deep love story and this present absence ground where Allie is situated disrupts Gregory's credibility or genuineness in yearning for a relationship with Allie. The only data granted to the reader about their relationship is that Allie broke up because "he was too possessive" and she "said she couldn't breathe, being with him was like being married" ("A Short History of Hairdressing" 13). Finally, in the third part of the story, it is disclosed that Gregory is middle-aged, married to his former girlfriend; Allie is now his wife and they have two children, which is the only information given about their marriage. On the other hand, the narrator lets Gregory give detailed information about the prices in the barbershop; that is, the haircut that started out costing one and three-pence has inflated to twenty-pounds including tips. The boy who used to look at the barber as "torturer in chief" in the first part of the story now has become a man adapted to small talks in the barber with his regular stylist as the narrator reports: "It had only taken him about twenty-five years to get the right tone" (18). The knowledge that time is almost at an end for Gregory is not enough to gear to a great change in him. What is more, the only boldness or triumph that Gregory could display in his old age is to show courage to refuse, when presented with the mirror, to inspect the back of his head as he is proud to unveil his so-called transformation as follows: "Well, I've stopped being afraid of religion and barbers" (19). The only transformation that an old man has gone through is not having the energy to care about the routines in a barber shop. As opposed to Gregory, not much is revealed about Allie; the narrator does not inform the reader about her workplace if there is any, her tastes or what kind of a transformation she has experienced with old age. In a collection, where all the stories build themselves on old men looking back to their bygone years, this kind of small change can ironically only be defined with absence. The lack of a deep change accompanied with old age runs parallel with the presence of another feeling, that is, seeing the woman and relationships from a patriarchal eye and thus not being able to achieve intersubjectivity with any woman and not having a mature character. In his own wording, his life, he admits, has been one long cowardly adventure.

Two other women who are set in the nexus of present absence are Pamela and Babs in the fourth story of the collection titled "Hygiene". These women are portrayed in light of the patriarchal discourse and neither of them is delineated to contribute emotionally or spiritually to the relationship with Jackson, the retired major. The male protagonist cannot be said to have gone through a change or a transformation with old age having been stuck in the dictations of binary logic. Pamela is Jackson's wife and Babs is a prostitute working at a brothel whom he has been seeing annually for more than twenty years. In his marriage and his extra-marital affair until Babs dies at an age when she is described as "rather elderly" (79) by one of her colleagues, Jackson has not 
experienced any moment of intersubjectivity, at least not to the readers' knowledge. The retired major Jacko Jackson's life with his wife Pamela has been so tedious and boring. In line with Jacko's feelings the narrator's depiction of the woman includes humiliation and degradation as she is accused of not being able to perform several actions as men do, like driving or parking a car. She is just another incapable woman in the eyes of Jacko:

She'd be in that car park grinding down the wheel-rims on the concrete kerbs as she tried to manoeuvre the Astra closer to the token-slot thingy. She always complained that the men who designed the barriers didn't realize that women had shorter arms than men. (69)

However, for Jacko Pamela is inferior in most of the skills, and he openly informs his wife about it: "He said that was no excuse for playing argy-bargy with the kerb, if you couldn't reach you should just get out, woman" (69). The only constructive feedback he could give about his wife is that "[s]till, she made good coffee, he's always given her that" (70). From Jacko's focalization and the narrator's wording, the impression one gets about his wife is that she is a typical inapt woman who cannot be enough on her own but needs a man's supervision. Evaluating Pamela in such a negative light that is based on dualistic logic and binary stereotypes, Jacko creates a legitimate background for his extra-marital affair with Babs. He simply cannot be happy with Pamela and thus, he needs some relief and consolation in Babs. In the story, Jacko makes his annual trip to London for a regimental dinner, yet with all his mind set on his yearly rendezvous with Babs. For years, the prospect of this meeting has kept his spirits young and energetic as opposed to the tedious life he leads with his wife Pamela.

Babs, compared to Pamela, must be promising a lot as a more competent and a better woman for Jackson; however, she is still conspicuous by her absence. Considering the length of time, more than twenty years, that Jacko has spent with Babs, one might prospect for a fuller, more detailed and multidimensional way of characterization for her. Yet, she is depicted as absentpresent who is devoid of deep emotions, ties or attachment. At his first reference to Jacko's relationship with Babs in the story, the narrator, first of all reports what kind of a transformation he has gone into about his tastes:

He was an orderly man, with orderly expectations and pleasures. Even if those pleasures were not as strong as they once had been. Different, let's say. As you got older, your head for the sauce wasn't what it used to be. You couldn't tie one on like in the old days. So you drank less, enjoyed it more, and ended up just as newted and owly as before. Well, that was the principle. Didn't always work, of course. (71)

The narrator would just like to express that Jacko's sexual desires or urges are still active and live though they have changed forms. When it is time to elaborate on Babs, Jacko is highly superficial and quite straightforward in sharing his sexual experiences with her. What is more, he relates his sexual 
appetites with obscene analogies. He refers to Babs for the first time in the story with statistical information about their sexual intercourse:

And the same with Babs. How he remembered that first go-round, all those years ago. Surprising he did, given his condition at the time. And that was another thing, being newted and owly didn't seem to make any difference to the honourable member then. Three times. You old dog, Jacko. Once to say hullo; once for the real business; then once more for the road. Well, why else did they sell rubber johnnies in packets of three? (71)

Obviously, he is proud of his sexual performance in a place, a brothel, where woman is a mere commodity and exploited in the most terrible way. Trying to explain his motivation about having this kind of an affair, he somehow relates it to his wife: “He didn't blame Pamela. Some women just went off it after the change. Simple matter of biology, nobody's fault. Just a question of female wiring" (72). Although he asserts that he does not blame Pamela, the single woman, what he does is imputing his cheating on his wife to all women as a category and softening his voice by putting the blame on female nature: "No surprise, given that Old Mother Nature is decidedly of the female persuasion" (72). With the help of the analogy that he draws, he tries to simplify the experience of cheating his wife and to show it as something common for all men. He contrasts man's and woman's body and their sexual practices from a dualistic perspective saying that: "All he was doing was making sure his machinery was still in working order. Old Father Nature still lubricating the parts. A matter of hygiene, really" (72). His being active and his wife being passive sexually is contrasted in the present/absent opposition; that is, the narrator categorizes man and woman in a hierarchical way. In this light, woman is grounded in present absence.

Jacko's justification for choosing and having an affair with Babs is absent of deep and legitimate explanations. Seeing this loophole, the reader will find Jackson's possible yearning for the good old days unjustifiable. Explaining the present reasons why he has chosen Babs is straightforward and does not include any depth: "Babs was a nice girl, she was there, she was blonde, and they'd rung the gong three times that night. There wasn't more to it than that" (73). This is what he can tell about Babs as she is situated in the grounds of present absence and for the next year's meeting, Jacko feels anxious if she might not remember him:

The following year he couldn't be sure Babs remembered him, but even so she'd been pleased to see him. He'd brought her a bottle of champagne on the off-chance, and that had somehow sealed things. He'd stayed the whole afternoon, told her about himself and they'd rung the gong three times again. (74)

As it is seen from Jacko's reminiscences, twenty years have passed without any remarkable memory or anything deep in emotion. From what he says about Babs one can see the absence(s) of reasons to attach himself to her. These gaps 
and ruptures reveal themselves in the presence of the dominant patriarchal discourse; that is, the troubled crude reductionist look at women.

Reducing the existence of women to stereotypical images like server, object for fun, sexual partner, Jacko observes just superficial things in the women in his life and these are doomed to change with old age. He reports how Pamela has changed as follows:

Of course they'd changed. Everyone changed. Pamela for a start; the children going, the garden, the thing she'd developed about dogs, the way she'd cut her hair as short as the lawn, the way she was always cleaning the house. (74)

The things revealed here as indications of change with old age are absent of deep introspections and observations. He does not mention anything more than the things that everyone could observe in Pamela's life. How he observes the changes in Babs is no different with Pamela:

he acknowledged that her hair was no longer quite the blonde it had once been. And after he'd persuaded her not to go into retirement she'd changed too. Didn't like undressing in front of him. Kept her nightie on. Got heartburn from his champagne. ... Turned out the light more and more. Didn't quite make the effort she once had to get him started. Slept when he slept; sometimes before. (75)

The changes he observes occur are dull and not consequential, but at the same time, his description of Babs and their routine unveil how he is being preoccupied with himself and egotistical by not letting her retire from working at a brothel. The lack of subtle and delicate details about Babs proves that Jacko fails to achieve intersubjectivity with Babs as well. This can also be understood when he reduces her existence to an object who is there merely for having sex and feeding his pride of masculinity, as his next sentence reads as follows: "and still ring the gong three times in a row. ... Choccy biccy Jacko? Yes, there was a bit of that. But also, you're a real man, you know that Jacko? There aren't that many real men around, they're dying breed, but you're one of them" (76). In this affair, although his real name is James Lewis, he becomes Jacko, which sounds either like a nickname kids would use or which can be associated with men who are preoccupied with their physical or sexual strength. This kind of image also makes it improbable for Jacko to have a symbiotic relationship with any woman and thus to yearn for shared past experiences and feelings.

Another absence or absent ground about Babs is discovered upon Jacko's annual visit to the brothel; that is, Jacko finds out that he does not even know her real name. Entering the place and learning that Babs is dead, he is surprised to find out how little he knows about Babs. His dialogue with other women there reveals that they have found it hard to recognize whom Jacko is talking about. Then, he learns that Babs is called Nora there. His dialogue with the other women seeking for Babs is worth quoting at length:

'Babs,' he'd repeated. 
'I'm Babs,' the blonde replied.

'You're not Babs,' he said.

'If you say so,' she replied.

'You're not Babs,' he'd repeated.

The two women looked at one another, and the blonde had said in a casual way, hard way, 'Look Grandpa, I'm whoever you want, right? (78)

Anyone can be Babs there; that is, no woman is unique. In the absence of such essential knowledge about Babs, one thing is clear; in this kind of a patriarchal space woman cannot be taken as an individual or a subject but rather depicted as a category or a stereotype. With this sense of an understanding his yearning for anything meaningful or deep in the past will be beyond reliability and credibility. The only genuine change the reader sees is that he is getting more and more impotent in sexual performance as he gets older. How terrible he feels about his helplessness is evident when he agrees to have sex with one of the other women in the brothel learning that Babs is dead: "The dark woman said 'Well, do you still want what you've come for? ... He'd gone into what used to be Babs's room ... She had asked him what he wanted. He hadn't replied. She'd taken some money and handed him a rubber johnny" (79-80). As Thomas Mallon asserts in his review in The New York Times, this collection of stories "has plenty of sharp, even cruel, comic pleasures" (Mallon). Jacko's quest for pleasure, however, ends in fiasco. Upon his failure, he feels furious, gets out of the room, and walks in the street repeating the same things he keeps using in remembering Babs: "How it used to be. Once to say hullo, once the real business, once more for the road. You were a tiger in those days, Jacko" (82). For this very moment, Merritt's observation rings true when she asserts as follows: "In The Lemon Table, love and sex are to be preserved reverently in memory by the old but are seen as a foolish indulgence if pursued into the present" (Merritt). Jacko perceives the world and the others from a solipsistic mind; the things he recollects are all about himself and have almost nothing to do with the others.

Another image the narrator creates for the women in the stories is passive, silent or incapable of achieving anything worthy in the eyes of men. With these kinds of women, male protagonists not having established a sense of meaningful belonging, deep emotions or attachment, Barnes can be said to use sex as a screen or means to conceal this absence. When sex is removed from the scene, one will find it hard to see any ground for a yearning for the past or for any experience. Thus, it is difficult to trace any genuine transformation with old age, in the stories. Ruth Franklin, who occasionally contributes to The New Yorker as a book critic, refers to this absence in a sarcastic way: "Sex in Barnes is all loins, no fire" (41). The "fire" that Franklin refers to may well be the absent intense feeling that is expected to be between partners who claim to love one another deeply. In the second story of the collection, the most curious one at the same time, titled "The Story of Mats Israelson," this absence is much more revealed with an unconsummated love affair between two married 
people. Barnes's story and the legendary story of Mats Israelson are expected to run parallel in themes or at least to flourish within the similar framework. However, neither of the stories achieves to arouse the atmosphere for platonic love which is generally characterized by persistence and diligence. Among many reasons for this absence, not being able to portray fully developed women characters stands out the most.

In Barnes's story, which takes place in Sweden in 1898, Anders Boden, a married sawmill manager, meets his married neighbour Barbro Lindwall every week on the boat up the lake. The narrator portrays another silent and a shallow character with Barbro Lindwall, which makes a platonic love story to have an enchanting effect on the reader difficult. While the reader is provided with many details about Anders Boden as he is the one who always talks to Barbro about whatever comes to his mind, about Barbro Lindwall there are just a few clues presented as she is the one who simply listens. Even in description, while the narrator creates a vivid picture for Anders Boden like: "a short, flaxen-haired man" and that "he would run to fat," the narrator's wording for Barbro Lindwall is rather obscure: "Mrs Lindwall was less remarked upon, being neither menacingly pretty nor contemptibly plain, neither vulgar nor soignée in dress, neither pushy nor reclusive in manner" (27). There is nothing specific and/or special about her; "[s]he was just a new wife" in that small town (27). What is more, she is referred to in a ridiculous light as her intelligence keeps being humiliated. When Axel Lindwall is about to propose to Barbro her reply can be taken as funny, even stupid: "Gossip said when Axel first handed Barbro into the rowing boat they acquired that summer, she had asked him, anxiously, 'You are sure, Axel, that there are no sharks in the lake?'” (27-8). She is far from answering the marriage proposal. In contrast to Barbro Lindwall's tactlessness, Anders Boden is an informative man with a high degree of expertise in his field - "the general manager of the sawmill" - and ready to share with her (25). His range of expert knowledge is even diverse: "He told her how once, at Bergrsforsen, where an iron bridge spans the rapids, he had watched four hundred men at work, catching the logs as they emerged from the river" (30). More than that "[h]e explained to her, like a man of the world, the different systems of marking" enlightening her with the details about timbers of various origins like Swedish, Norwegian or Prussian (30). Barbro is just another silent woman who cannot forward the communication and thus the story fails to kindle any emotions associated with platonic love.

The story of Mats Israelson, the local legend where the story takes its title from, cannot achieve to be a parallel resonance for Anders and Barbro's love story. This platonic love story is the story of a man whose body fell into a copper mine and was discovered, perfectly preserved, forty-nine years later, identified by an old woman who had been betrothed when he disappeared. Knowing that Barbro likes "a man to tell ... [her] what he knows," Anders is quite enthusiastic to share the story of Mats Israelson with her (42). Anders Boden recounts this story to Barbro Lindwall on the boat in such a bland 
fashion that it takes neither Barbro's nor the readers' attention. Anders notices her lack of interest talking to himself: "Embarrassed, he told her the story of Mats Israelson, but he told it in the wrong order, and too quickly, and she did not appear interested" (31). He has attempted to narrate the story again without success: "He went about his work and in free moments thought about how she had not attended to the story of Mats Israelson" (33). In all their meetings, Barbro is depicted as a silent, passive or mysterious one who does not have the courage to announce her love for him. She openly reveals her being shallow with some apologies: "I'm sorry,' ... 'I have little imagination. I am only interested in what really happens. Legends seem to me ... silly" (31). She is like a false female character in a short story which revolves around a legend. In other words, Barnes's story cannot flourish either depending on the local legend or the platonic love story between Anders and Barbro. The absence of a genuine love to feel nostalgic about the past is an indication of a troubled look at women as a stereotype who is ready to obey the dictations of men and to be passive and silent. Anders's depiction of Barbro is still so dull and from such a strong patriarchal viewpoint that it is almost impossible to appreciate and acknowledge such kind of a love or obsession. Anders's first time talk about how he falls in love with Barbro is cold and remote:

He thought: of course, now I see, the fact is, I have been in love with her since we first met on the steamboat. I would have not have come to it so soon had not Gertrud helped me there. I never imagined her sarcasm had any use; but this time it did. (32-33)

His way of falling in love seems not to have anything to do with Barbro but his wife's sarcastic remarks push him towards Barbro. Barbro also similarly "was not convinced of her feelings for Anders Boden until she recognized that she would now spend the rest of her life with her husband. First there was little Ulf and then a year later, Karin" (35). Soon, Anders finds out that Barbro is pregnant and they stop seeing each other. Anders proves not to enchant Barbro in any of their meetings when Barbro is generally quiet and not contributing to the spirit of a relationship.

The only opportunity for Anders and Barbro to reveal their so-called love is wasted due to lack of communication and not being able to speak to one another from the depth of their heart. The probable love scene once again results in disillusionment and disenchantment. Barbro Lindwall receives a letter after twenty-three years from Anders asking for her immediately to a hospital as follows: "Dear Mrs Lindwall, I am in hospital here. There is a matter I would very much like to discuss with you. Would it be possible for you to visit me one Wednesday?" (39). He has acted courageously by writing a letter to her on his deathbed and decides to talk about his undying love for her. Receiving the letter in her old age, she thinks it is life/death situation and that she has to attend the invitation asking her husband's permission. However, Anders decides not to share with Barbro that he is about to die thinking that "it was important not to tell her that he was dying" as that might "put an unjust burden on her" (40). In order to disguise the truth he creates a scenario which is as 
follows: "He told the nursing staff that a dear cousin was coming to visit him, but because of a fragility of the heart must on no account be told of his condition" (40). What is more "[h]e asked them to trim his beard and comb his hair. When they had gone, he rubbed a little tooth-powder into his gums, and slid his damaged hand beneath the bedclothes" (40). Once Barbro arrives at the hospital, Anders starts impersonating a healthy and a cheerful man, which makes Barbro feel furious and cheated upon. All her questions are replied in a negligent way:

'I thought you were ill.'

'No, no,' he replied cheerfully. [...]

'I thought you were dying.'

'I'll last as long as any fir tree on the Hökberg.' (42)

The responses he gives to Barbro are not congruent with his tone in his letter. His attitude makes Barbro feel like she has been dumped and humiliated as he denies his dying and angers her by appearing to be a mere seducer. Her inner voice is as follows:

The vanity of the man. What a false picture she had carried of him all these years, as a person of discretion, tact, of an almost blameworthy inability to put his case. In truth, he was just another man, behaving as men did in books, and she was just another woman for believing otherwise. (43)

The narrator's quite straightforward depiction of the roles of genders is revealed with Barbro's inner voice. Counting on ready-made formulas about traditional gender roles dictated by patriarchal discourse makes couples experience anything genuine and legendary difficult. The stereotypical images behind the characters generate a kind of absence in having unforgettable shared experiences. This absence creates a rupture or a loophole in characters' look at the past with nostalgic eye. Yet, this absence is indeed the presence of a masculine way of seeing the image of woman, that is, man is the active story teller and woman is the passive listener and taking orders. Thus, even a story of love loses its effect on this short story.

In this collection of stories speaking mostly on behalf of men, another image Barnes creates for women is a comic figure embellished with grotesque nuances. As opposed to male characters, whose deeds, actions and motives are fully explained and legitimized, the women are absent by providing the readers with so little access to their characters, objectified or ridiculed in a grotesque mood and context. Seeing these women in such a distorted light, one may find it difficult to feel nostalgic for a relationship with this kind of a woman or for the past days with her. In the story titled "Bark," the protagonist is sixty-oneyear-old Jean-Etienne Delacour and the story gives wide coverage to how his routines and way of living have changed in course of time. He used to be a gambler and an obese; however, at the outset of the story, it is revealed that he has been into a strict diet, given up gambling and taken up exercise. About his 
old habit of gambling, the narrator reports that he used to be a compulsive gambler:

Wherever dice were thrown or cards turned, wherever two or more beasts could be induced to race against one another for the gratification of spectators, Delacour was to be found. He had won and lost at faro and hazard, backgammon and dominoes, roulet and rouge et noir. He would play pitch-and-toss with an infant, bet his horse on a cockfight, play two-pack patience with Mme $\mathrm{V}$-, and solitaire when he could find no rival or companion. (124)

It is reckoned that he has made a big change for the better and "his gourmandism had put an end to his gambling. Certainly, there was not room in such a man for both these passions fully to express themselves" (124). About his being fond of eating and drinking, again he has been extremist: "[h]e ate meals fit for a cardinal, ... [h] e would discourse on the point of esculence of every foodstuff, ... [h] e was also a familiar of the bottle. If grapes were offered as a dessert, he would push them away with the words, 'I am not in the habit of making wine in the form of pills"' (124). Yet, this kind of person proves to have such strong will that he quits eating too much in his old age. The narrator gives detailed information about what food he rejects, what he prefers to eat and his new eating style. The reader is informed about how determined he can be when he is surrounded by "bouillon," "a grilled-hare," "a pigeon-casserole," "vegetables," "cheese and fruit jellies" (123). Instead, he prefers "a single pear and a slice of bark cut from a tree" (123). It can be said that with all these details presented he has been proven to be present in the text.

Contrary to Delacour, Mme Delacour is almost absent in the story. That she has been revealed to be dead at the very beginning does not give her any chance to assert herself; thus, she is absent by not contributing to any part of the story. Her first name is not mentioned and she is either Delacour's wife or Mme Delacour. How she evaluates her husband's bad habits is very much shaped in line with the conventional gender roles: she is another woman who is preoccupied with keeping her husband at home: "Delacour's wife had approved his choice of vice, since gourmandism is more likely to keep a man at home than gambling" (124-5). Apart from this, the only information about her is that she has adopted the same bad habit with her husband: "The years passed, and her silhouette began to ape that of her husband. They lived plumply and easily until one day, fortifying herself in mid-afternoon while her husband was absent, Mme Delacour choked to death on a chicken bone" (125). Her physical appearance is depicted with repulsive wording and the way she dies can be regarded as grotesque. How this event is narrated from Delacour's viewpoint manifests how she is ridiculed and portrayed as a comic figure: "Jean-Etienne cursed himself for having left his wife unattended; he cursed his gourmandism, [...] for having lodged the chicken bone at just such a murderous angle in her throat" (125). The register and the tone here are satirical and degrading; Delacour obviously makes fun of her way of eating and dying of choking on a chicken bone. 
Two women related to Delacour in the story are present for reasons like, serving for his well-being and health or facilitating his life. Starting with his wife, Mme Delacour's death is of use for Delacour as the "death of his wife had brought a small legacy" (126). Though said to be small, with this bequest, Delacour can devise a scheme and be a part of great investment in building municipal baths. Soon, with this amount of money and chance, Delacour becomes the only owner of the baths and a beneficiary of the services offered there. In order to be healthy Delacour adopts a certain pattern in his daily routines: "He would rise early, eat a single fruit, drink two glasses of water, and walk for three hours. Then he would visit the baths" (128). After having been an obese and a gambler for so long, getting older and older he takes his lesson and starts to take care of himself: "Twenty minutes before supper he would cut himself a fresh slice of tree bark. While others ate their life-shortening concoctions, he would expatiate upon general threats to health and the lamentable impediments to human immortality" (129). Paying that much attention on his health and well-being and benefitting from his privileged position in the baths, Delacour also claims that "a reliable mark of health in the human male was the frequency with which he engaged in sexual connection" (129). Thus, for all health related reasons, Delacour "entered into an arrangement with a maid at the baths, whom he visited once a week" (129). Jeanne, a maid in the baths, is again just another woman who is there to serve for his well-being. To be able to live longer apart from following a strict diet, Delacour starts to have sex with Jeanne regularly. The way he talks about women in her life is quite patriarchal and sexist: "He began to visit Jeanne more frequently. She did not question this, and listened as he talked of legal matters she rarely understood" (133). Upon her informing him that she is with child, his answer is totally emotionless:

One day she informed him that she was with child. 'Twenty-five francs,' he replied automatically. She protested that she was not asking for money. He apologized - his mind had been elsewhere - and asked as if she was confident the child was his. (134)

The way he talks to her can be taken as a symptom of his troubled viewpoint towards women.

Delacour reveals his problematic look towards the nature of women and affairs to his close friend Lagrange, who is another beneficiary and investor of the baths. The women he refers to are portrayed and gauged in degrading and pitiful positions:

When I was a young man, in my army years, before meeting my late wife, I naturally accommodated myself with the sort of women who made themselves available. Nothing in those experiences of my youth advised me of the possibility that carnal delight might lead to feelings of love. I imagined - no, I was sure - that it was always the other way round. (131) 
Visiting Jeanne frequently and being served only in every way, Delacour thinks that he is in love with her; the "carnal delight" as he refers to his affair with Jeanne makes him fall in love with her. While unburdening himself to his close friend about his feeling of love which is instigated by the carnal delight, he still confirms ages old stereotypes about genders and hierarchies in between genders. His introspections about love make it clear that he associates men with presence and the primary, while women are secondary and absent. Here is the analogy he draws between the sexual practices of people and animals, like rabbits and bees. He spices and consolidates his argument with the help of some local laws as follows: "So long as the owner follows his bees as they swarm, he has the right to reclaim and take possession of them again. But if he has failed to follow them, then the proprietor of the ground on which they alight has legal title to them" (131). Obviously, he refers to Jeanne and his affair, which he evaluates in light of master and a commodity dichotomy. His anthropocentric look at nature and animals is another hint for the absence of free space where beings other than men may have the chance to claim for a better living.

To conclude, first of all, as Frank Kermode in his review in The Guardian suggests " $\mathrm{t}] \mathrm{his}$ is a book about old age and disappointment, among other things" (Kermode). Barnes tries to lighten this grave tone by intermingling sex and old age yet his fiction provides little access to the deeper questions within. This paper aims to carry this observation one step further by claiming that the absence of such deep feelings makes the idea of yearning and having a nostalgic look towards the past problematic. Franklin in a similar line asserts that Barnes "dreams up some nicely unconventional figures and puts them in provocative scenarios, but he fails to discover any emotion richer than a condescending pathos" (40). This absence is, what is more, a reflection of the presence of another feeling, that is perceiving love within the patriarchal framework by either objectifying or seeing the woman as passive, unintelligent, dull, trivial or as a commodity. In this light, Merritt's observation that "love rarely works according to anyone's hopes and expectations" rings true (Merritt). That is why, the stories under focus of this study cannot serve the purpose of clinging to the past which involves deep love and mutual sharing between couples. We, as readers having to deal with these loopholes, may well be embarrassed or feel pity on behalf of these old men only if they might have spoken to us in a deeper way in a collection aiming to gear to profound changes with old age.

\section{Works Cited}

Barnes, Julian. "A Short History of Hairdressing." The Lemon Table, Picador Pan MacMillan, 2005, pp. 1-23.

---. "Bark." The Lemon Table, Picador Pan MacMillan, 2005, pp. 121-137.

---. "Hygiene." The Lemon Table, Picador Pan MacMillan, 2005, pp. 67-85.

---. "The Story of Mats Israelson." The Lemon Table, Picador Pan MacMillan, 2005, pp. 23-49. 
Franklin, Ruth. “I Beg Your Pardon.” New Republic, vol. 231, no. 11/12, Sept. 2004, pp. 39-41.

Kermode, Frank. "Age has not withered him." The Guardian, 13 March. 2004. Web. 12 September 2019.

Leitch, B. Vincent. Deconstructive Criticism: An Advanced Introduction, Columbia University, 1983.

Mallon, Thomas. “As Young as You Feel.” The New York Times, 27 June. 2004. Web. 12 September 2019.

May, Todd. Reconsidering Difference, Pennsylvania State University, 1997.

Merritt, Stephanie. "Things can only get bitter." The Guardian, 14 March. 2004. Web. 12 September 2019.

Norris, Christopher. Derrida, Harvard University, 1987.

Spikes, Michael P. "Present Absence Versus Absent Presence: Kripke Contra Derrida." Soundings: An Interdisciplinary Journal, vol. 75, no. 2/3, 1992, pp. 333355. JSTOR, www.jstor.org/stable/41178579. Accessed 10 January 2020. 